\title{
The Interaction between Oil Price and Basic Macroeconomics Indicators: Evidences from Russia
}

${ }^{1}$ Dmitry V. Rodnyansky, Damir R. Baygildin.

${ }^{1}$ Kazan Federal University, 420008, Kremlevskaya 18, Kazan, Russia. Email:drodnyansky@gmail.com, Contact.8 8 (843) 231-54-79

Received: 15th December 2017, Accepted: 20th December 2017, Published: 31st December 2017

\begin{abstract}
This study empirically analyzes the causation between GDP, unemployment rate, inflation and oil price in through analyzing Russian quarterly data from 2005:Q1 to 2014:Q3 and employing Vector Error Correction (VECM). The main findings of the paper are in line with general theory and are as follows: i) changes in oil prices in direct ratio affect the level of production, in other words increase in hydrocarbon cost pushes Russian economy up, ii) high oil price, among other things, causes the unemployment rate in Russia to decline, iii) in the short run, inflation favorably, but weakly influences the level of production as well as employment in Russia, iv) unemployment rate in Russia, as expected, has adverse impact on the total output level, v) in accordance with error correction terms GDP and unemployment rate needs about 3 quarters to return to the equilibrium level after the structural changes. Based on the results, some policy recommendations are presented.
\end{abstract}

Keywords: Russia, Oil Price, GDP, Inflation Rate, Unemployment Rate, VECM.

\begin{abstract}
Introduction
Russia ranks as the world's second largest oil producer and exporter with the market shares of $12.6 \%$ and $12.9 \%$, correspondingly ${ }^{1}$. The importance of hydrocarbon sector for national economy is not questioned. Income from crude oil and refinery products export accounted for about $43 \%$ of Russian export revenue in 2016, while nonoil sector provided only $46 \%$. Besides, oil and gas sector not only constitutes about $40 \%$ of Federal budget and almost $16 \%$ of Gross domestic product (GDP), but also supplies the significant share of investment demand ${ }^{2}$.

Over the past 15 years Russian GDP has experienced upward tendency, namely from 2000 to 2015 it had increased by $76 \%$, taking in account crisis of 2008 2009. This growth from the beginning of 2000s was accompanied by the high oil prices and constantly rising volumes of crude oil and refinery goods production (Figure 1). At the same time inflation rate along with unemployment rate demonstrated significant fall from almost $20 \%$ and $11 \%$ in 2000 to $6 \%$ and $5.5 \%$ in 2016 , respectively.
\end{abstract}

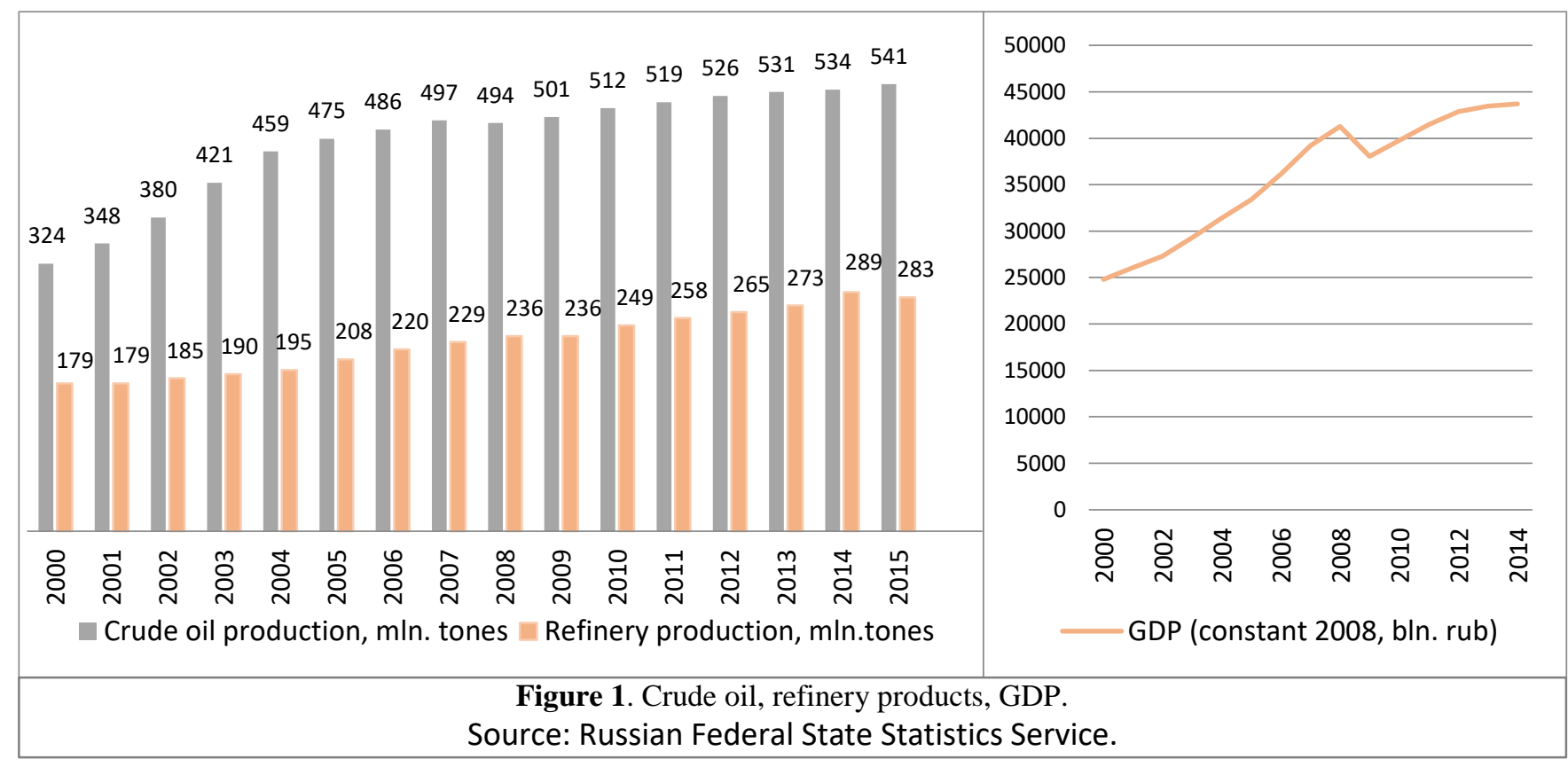

1 Source: BP Statistical Review of World Energy 2017, available from: www.bp.com
${ }^{2}$ Sources: Ministry of Finance of Russian Federation, Central Bank of Russian Federation. 
Although dependency of macroeconomic factors on oil price has been quite debatable issue for a long time, most researchers agree that oil price fluctuations considerably influence the economic activity, but the directions of effect are expected to be different in oil - importing and oil exporting countries $[1,2]$. The general theory suggests, that increase in oil price, which is the basic input to production, leads to rise in manufacturing cost which it turn results in the reduction of output. Besides, high oil prices strengthen the exchange rate of the oil-exporting country leading to the shrink of demand for non-oil exports. In addition reduction of output causes plants to close, wages rate to decrease and unemployment rate to rise [3]. On the other hand, increase in oil cost leads to accumulation of additional revenue in oil exporting countries which transforms to increased government expenditures resulting in production growth. Furthermore, high oil prices in oil-exporting countries not only stimulate reinvestments of additional income by oil companies, but also it favorably affects general investment activity through maintaining low interest rate, which in aggregate significantly enhance the output level [4].
There are plenty of theoretical investigations in Russia that analyze the sensitivity of macroeconomic factors to changes in oil cost. Some studies claim that Russian economic development fully depends on dynamics in oil market [5], while several researchers suppose that Russian economy exhibits significant growth capabilities in the absence of growth in the oil price [6]. However, there is a scarcity of studies which empirically investigate the interaction between price of oil and basic macroeconomics factors.

Therefore, the purpose of the investigation is to empirically identify the nature of effect of dynamics in oil prices on the three basic macroeconomic indicators (GDP, inflation and unemployment) of Russia. The research is expected to confirm or reject the hypothesis that stable economic development and descending unemployment rate since the beginning of the 21 century was determined, among other things, by the favorable oil prices. The Vector Error Correction model (VECM) is employed. The paper is organized as follows. Section 2 describes the data and methodology. Section 3 introduces the empirical results. Section 4 presents the discussions of estimated model outcomes. Section 5 summarizes the research.

\begin{tabular}{|c|c|c|c|c|}
\hline Variable & Name & Source & Period & Description \\
\hline $\begin{array}{l}\text { Gross Domestic Product } \\
\text { (GDP) }\end{array}$ & GDP & Rosstat & 2005:Q1 - 2014Q3 & $\begin{array}{l}\text { Gross Domestic product of } \\
\text { Russian Federation, } \$ \text {. }\end{array}$ \\
\hline Price of crude oil. & OILP & Reuters & 2005:Q1 - 2014Q3 & Price of Brent oil, $\$ / b b l$. \\
\hline Inflation rate & CPI & Rosstat. & 2005:Q1 - 2014Q3 & $\begin{array}{l}\text { Consumer price index. } 2010= \\
100 \text { (base year). }\end{array}$ \\
\hline Unemployment rate. & UNEM & Rosstat. & 2005:Q1 - 2014Q3 & Unemployment rate. \\
\hline Dummy variable. & D & - & - & $\begin{array}{l}2008-2009 \text { crisis } \\
\text { variable. }\end{array}$ \\
\hline
\end{tabular}

\section{Data and Methodology.}

The model used in the investigation includes 4 variables, namely GDP, oil price, inflation rate and unemployment rate. The sources of data and detailed series description are presented in Table 1. All variables are adjusted to economic crisis of 20082009 by dummy variable (accounts for sharp economic fluctuations) and converted into the logarithmic form. The timespan under consideration is from 2005:Q1 to 2014Q3, giving 38 observations.

To identify the order of integration of the variables, Augmented Dickey Fuller test (ADF) was applied for each series. The outcomes of the test are given in the Table 2 below. It is clear that ADF test failed to reject the null hypothesis of the presence of unit root for each variable and both specifications (intercept/intercept and trend) meaning that all series suffer from non-stationarity at level. After transforming variables into the first difference the problem of non-stationarity disappeared. Therefore, it can be concluded that estimated series are integrated of order one and we can proceed to verify the existing of cointegration and a number of cointegrating equations using Johansen's methodology in a multivariate framework. To take into account the linear trend in the data constant is included in the cointegration equation and VAR. 
Optimal lag length of 4 was determined by LR test, AIC method and SBIC method. Table 3 below presents the results of the test. To specify, we failed to reject the null hypothesis of three equilibrium cointegrating relations at the $5 \%$ significance level. Consequently, the stable long-run causation between the selected variables exists and we may proceed to carry out Granger-causality test.

\begin{tabular}{|c|c|c|c|c|}
\hline \multicolumn{5}{|c|}{ Augmented Dickey Fuller test (H0: Unit root) } \\
\hline \multirow[b]{2}{*}{ Variables } & \multicolumn{2}{|l|}{ Level. } & \multicolumn{2}{|l|}{ First difference. } \\
\hline & With intercept & $\begin{array}{l}\text { With intercept and } \\
\text { trend. }\end{array}$ & With intercept & $\begin{array}{l}\text { With intercept and } \\
\text { trend. }\end{array}$ \\
\hline LGDP & -2.512 & -2.141 & $-6.059^{*}$ & $-6.362 *$ \\
\hline LOP & -2.299 & -2.213 & $-5.283 *$ & $-5.378 *$ \\
\hline LINF & -0.753 & -1.976 & $-5.000^{*}$ & $-5.052^{*}$ \\
\hline LUNEMP & -2.235 & -3.003 & $-7.918^{*}$ & $-7.833^{*}$ \\
\hline $\begin{array}{l}\text { Order of } \\
\text { integration }\end{array}$ & - & - & $\mathrm{I}(1)$ & $\mathrm{I}(1)$ \\
\hline \multicolumn{5}{|l|}{ Critical values. } \\
\hline $1 \%$ & -3.607 & -4.187 & -3.614 & -4.196 \\
\hline $5 \%$ & -2.941 & -3.516 & -2.944 & -3.520 \\
\hline $10 \%$ & -2.605 & -3.190 & -2.606 & -3.192 \\
\hline
\end{tabular}

In the analysis, to capture the interaction between oil developed by Johansen $(1988,1995)$ was employed price and selected macroeconomics variables the Vector Error Correction model (VECM) which is $[7,8]$. The general form of the model is as follows:

$$
Z_{t}=\Gamma_{1} \Delta Z_{t-1}+\Gamma_{2} \Delta Z_{t-2} \ldots+\Gamma_{l-1} \Delta Z_{t-l-1}+\alpha \beta^{\prime} Z_{t-1}+e_{t}
$$

where $\Delta$ is the difference operator, $Z t$ is an $(n \times 1)$ vector of variables $=[$ GDP, OILP, CPI, UNEM, D], 1 is the number of lags, $e_{t}$ is an $(n \times 1)$ the vector of error terms. $\Gamma$ refers to an $(n \times n)$ matrix of parameters, providing the information about the short run relationship between variables. $\alpha$ and $\beta^{\prime}$ are $(\mathrm{n} \times \mathrm{r})$ adjustment and cointegration matrices, respectively, which contains information regarding the long-run relationships of series.

Applying general VECM model to our case we obtained the following equations for estimation:

$$
\begin{aligned}
& \Delta \log (G D P)_{t}=\gamma_{0}+\sum_{i=1}^{k} \gamma_{1 i} \Delta \log (G D P)_{t-i}+\sum_{i=1}^{k} \gamma_{2 i} \Delta \log (O I L P)_{t-i}+\sum_{i=1}^{k} \gamma_{3 i} \Delta \log (I N F)_{t-i}+ \\
& \sum_{i=1}^{k} \gamma_{4 i} \Delta \log (U N E M)_{t-i}+\mu e_{t-1} \\
& \Delta \log (I N F)_{t}=\gamma_{0}+\sum_{i=1}^{k} \gamma_{1 i} \Delta \log (I N F)_{t-i}+\sum_{i=1}^{k} \gamma_{2 i} \Delta \log (\text { OILP })_{t-i}+\sum_{i=1}^{k} \gamma_{3 i} \Delta \log (\mathbb{Q} \text { G } D P)_{\mathrm{t}-\mathrm{i}}+ \\
& \sum_{\mathrm{i}=1}^{\mathrm{k}} \gamma_{4 \mathrm{i}} \Delta \log (\mathrm{UNEM})_{\mathrm{t}-\mathrm{i}}+\mu \mathrm{e}_{\mathrm{t}-1} \\
& \Delta \log (\mathrm{UNEM})_{\mathrm{t}}=\gamma_{0}+\sum_{\mathrm{i}=1}^{\mathrm{k}} \gamma_{1 \mathrm{i}} \Delta \log (\mathrm{UNEM})_{\mathrm{t}-\mathrm{i}}+\sum_{\mathrm{i}=1}^{\mathrm{k}} \gamma_{2 \mathrm{i}} \Delta \log (\mathrm{OILP})_{\mathrm{t}-\mathrm{i}}+\sum_{\mathrm{i}=1}^{\mathrm{k}} \gamma_{3 \mathrm{i}} \Delta \log (\text { INF) })_{\mathrm{t}-\mathrm{i}}+ \\
& \sum_{\mathrm{i}=1}^{\mathrm{k}} \gamma_{4 \mathrm{i}} \Delta \log (\mathrm{GDP})_{\mathrm{t}-\mathrm{i}}+\mu \mathrm{e}_{\mathrm{t}-1} \\
& \left.\Delta \log (\text { OILP) })_{\mathrm{t}}=\gamma_{0}+\sum_{\mathrm{i}=1}^{\mathrm{k}} \gamma_{1 \mathrm{i}} \Delta \log (\text { OILP) })_{\mathrm{t}-\mathrm{i}}+\sum_{\mathrm{i}=1}^{\mathrm{k}} \gamma_{2 \mathrm{i}} \Delta \log (\text { UNEMP })_{\mathrm{t}-\mathrm{i}}+\sum_{\mathrm{i}=1}^{\mathrm{k}} \gamma_{3 \mathrm{i}} \Delta \log (2 \mathrm{c})_{\mathrm{NF}}\right)_{\mathrm{t}-\mathrm{i}}+ \\
& \sum_{\mathrm{i}=1}^{\mathrm{k}} \gamma_{4 \mathrm{i}} \Delta \log (\mathrm{GDP})_{\mathrm{t}-\mathrm{i}}+\mu \mathrm{e}_{\mathrm{t}-1}
\end{aligned}
$$




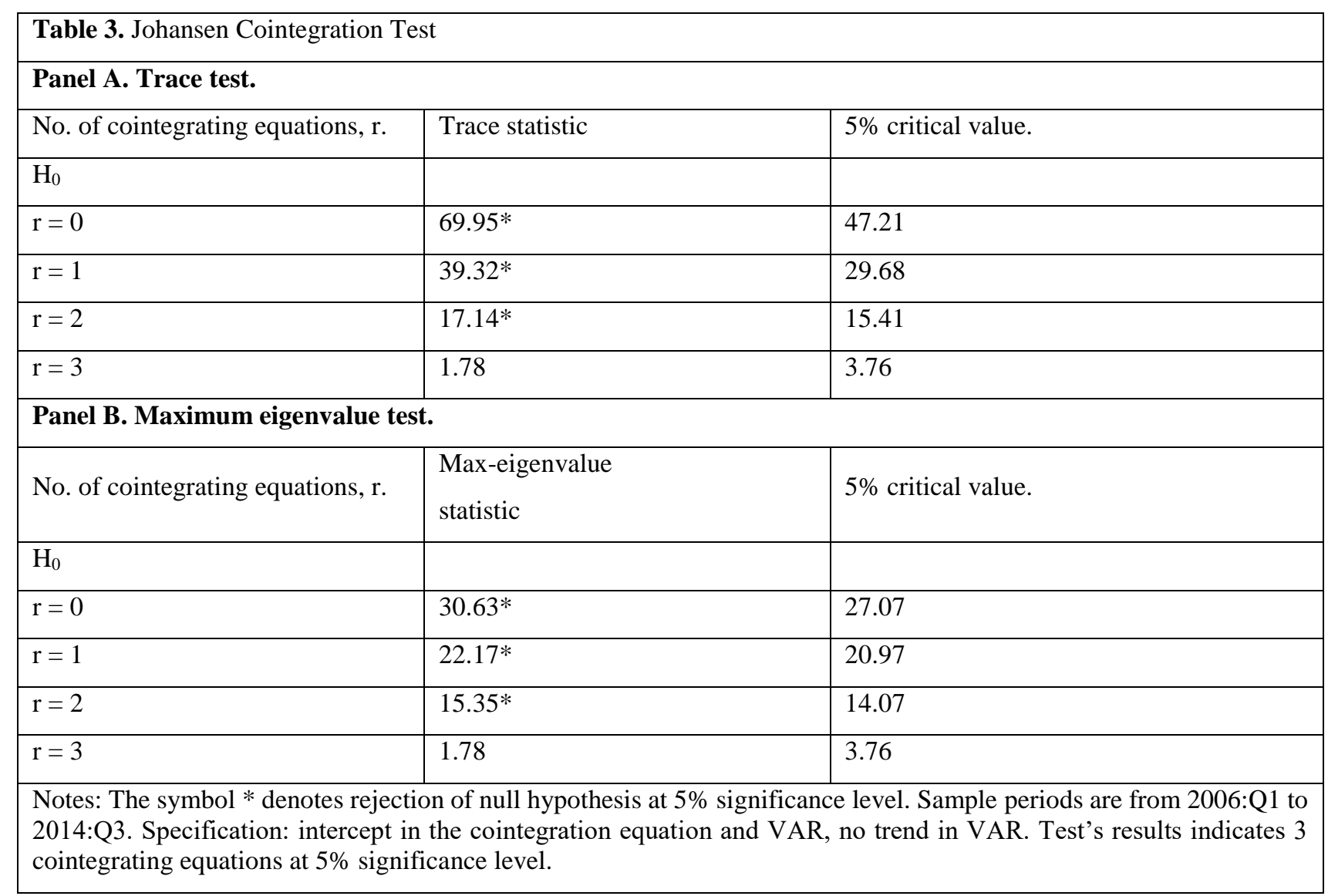

where $e_{t-1}$ is the error correction term (ECT), $\mu$ is the coefficient of ECT, $\gamma_{t}$ is the coefficients of variables. The negative and significant $\mu$ confirms the presence of long run relationship between estimated variables and indicates how fast the deviation from the longrun equilibrium relationship will be corrected. Finally to check the accuracy of obtained results the Lagrange Multiplier test proposed by Breusch and Godfrey (1981) was employed [9].

\section{Results}

Table 4 introduces the results of VECM estimation of four derived equations. The error correction term, which captures the long run dynamics relationship, is negative and statistically significant (-0.183) only in the equations $2 \mathrm{a}$ and $2 \mathrm{c}$, where GDP and UNEM acts as a dependent variables. This outcome indicates that GDP and UNEM adjust to their long run equilibrium at a relatively rapid rate $(18 \%$ and $16 \%$ respectively) after the structural shocks (disequilibrium). Moreover, the estimates of equation $2 \mathrm{a}$ confirm the existence of significant short-run causation between OILP, INF, UNEM and GDP. To specify, 1 percent increase in oil cost leads to rise in GDP by about $0.35 \%$. This finding corresponds to the general theory, which states that upward in oil price augments revenue of government and oil producing companies which in turn stimulates government expenditures and investment activity resulting in rise of total output. It can be concluded that positive effect of growth in oil price in Russia on GDP overcomes its negative consequences caused by the upward in the cost of production.

\begin{tabular}{|l|l|l|l|l|}
\hline \multicolumn{2}{|l|}{ Table 4. Vector Error Correction Model } & $\Delta$ LOP & $\Delta$ LUNEMP & $\Delta$ LINF \\
\hline VARIABLES & $\Delta$ LGDP & -0.59 & 0.26 & -3.02 \\
\hline$\Delta$ LGDP-1 $_{-1}$ & $\mathbf{- 0 . 6 7 * *}$ & {$[-0.94]$} & {$[1.00]$} & {$[-0.90]$} \\
\hline$[$ t-statistic] & {$[-1.97]$} & $\mathbf{1 . 2 3 *}$ & $\mathbf{- 0 . 3 0 *}$ & 1.31 \\
\hline$\Delta$ LOP $_{-1}$ & $\mathbf{0 . 3 5 *}$ & {$[4.04]$} & {$[-2.43]$} & {$[0.81]$} \\
\hline$[$ t-statistic] & {$[4.58]$} & 0.107 & -0.039 & -0.30 \\
\hline$\Delta$ LUNEMP $_{-1}$ & $\mathbf{- 0 . 0 9 1 *}$ & & & \\
\hline
\end{tabular}


Helix Vol. 8(1): 2852-2857

\begin{tabular}{|c|c|c|c|c|}
\hline [t-statistic] & {$[-5.30]$} & {$[0.15]$} & {$[-1.31]$} & {$[-0.08]$} \\
\hline$\Delta \mathrm{LINF}_{-1}$ & $0.04 * *$ & 0.10 & $-0.13^{*}$ & -0.21 \\
\hline [t-statistic] & {$[1.88]$} & [1.27] & {$[-4.02]$} & {$[-0.50]$} \\
\hline CONSTANT & -0.014 & 0.36 & -0.22 & -0.01 \\
\hline [t-statistic] & {$[-0.06]$} & {$[0.85]$} & {$[-1.23]$} & {$[-0.06]$} \\
\hline Error correction term & $-0.183 * *$ & 0.49 & $-0.16 *$ & 1 \\
\hline [t-statistic] & {$[2.08]$} & [1.36] & [2.66] & [0.74] \\
\hline
\end{tabular}

Besides, it is clear from the Table 4 that rise in unemployment rate unfavorably influence output of the Russia, namely $1 \%$ increase in unemployment cause GDP to fall by almost $0.1 \%$. Since the labor is the main factor of production, which provides revenue for people or, in other words, stimulates demand, the obtained results make sense. Although coefficient of inflation rate indicates significant and positive influence on the level of production, its effect is comparatively weak. It may be explained by the fact that inflation theoretically has both negative and positive effects on economy. The auspicious effect caused by the discouraging of savings, in other words, people and companies start to spend rather than to deposit money, which in the short term boosts the economy. On the contrary, inflation pushes up interest rate leading to reduction in spending and investments which in turn disrupt production. According to the estimated outcomes favorable influence of inflation rate on the level of output in Russia slightly exceeds its adverse impact.

In addition, the VECM estimation of equation 2c confirmed the advantageous effect of rising oil price on employment, specifically $1 \%$ increase in oil cost drives the unemployment rate down by about $0.30 \%$. Since oil prices boosts output production in Russia and labor is the basic factor of production it is logically to conclude that outcomes of estimation is in the line with general theory. Finally, it was found that sustained increase in the general level of prices slightly reduces unemployment rate which may be also explained by the rise of production level. To check the estimated equations for possible misspecifications, the Lagrange - multiplier test was carried out. It is found that there is no serial correlation in the estimated model and the obtained results are accurate and can be used for further implementation.

Table 5. Lagrange - Multiplier Test.

\begin{tabular}{|l|l|l|}
\hline Lags & LM-Stat & p values. \\
\hline 1 & 44.124 & 0.199 \\
\hline 2 & 37.847 & 0.447 \\
\hline 3 & 21.451 & 0.912 \\
\hline \multicolumn{2}{|l}{ Notes: $\mathrm{H}_{0}$ is no autocorrelation. Degrees of freedom is 37. } \\
\hline
\end{tabular}

\section{Discussions}

Russian oil sector is one of the basic drivers of national economy which shapes the most state revenues and trade balance of the country. In times of high oil prices, sustained economic growth accompanied by the stable macroeconomics indicators is observed. However, as soon as hydrocarbon market is going through the price fall, the national economy slowdowns or even collapses. The international crisis of 2008-2009 as well as economic difficulties of 2014-2015 is additional confirmation to the findings of the study. it is clear that this an excessive resource dependency leads to the range of destructive consequences as follows: i) export-based manufacturing sectors are stunted or precipitous declines [10], ii) substantial macroeconomic instability due to increased volatility of oil prices, iii) lack of competitive advantages in science, education and high tech, iv) inefficient government management, including government spending, institutional development, etc. 
This causation does not suggest to retreat from development of Russian natural competitive advantage, but notifies that certain measures to diversify the national economy need to be taken, namely:

i. To target a moderate national exchange rate, that is expected to provide understanding to non-oil exporters that their products will be cheaper on the external market and as a result more salable.

ii. To develop the financial market with "long term" money.

iii. To weaken fiscal and monetary stimulation since active government interventions reduce competitiveness, destabilize the efficiency of production, decreases investment resources and etc.

iv. To reduce the share of government in business, including partial privatization and reduction of excessive control.

v. To support the development of innovation institutes [11].

\section{Collusions}

This paper investigates the relationship between basic macroeconomic indicators of Russia and price for oil over the past 10 years employing the VECM and controlling for the economic shock of 20082009. The main findings of the study are significant and go in line with the general theory. To specify:

i. Changes in oil prices in direct ratio affect the level of production, in other words increase in hydrocarbon cost pushes Russian economy up.

ii. High oil price, among other things, causes the unemployment rate in Russia to decline.

iii. In the short run, inflation favorably, but weakly influences the level of production as well as employment in Russia.

iv. Unemployment rate in Russia, as expected, has adverse impact on the total output level.

v. In accordance with error correction terms GDP and unemployment rate needs about 3 quarters to return to the equilibrium level after the structural changes.

By results of the investigation, we can confirm the hypothesis that the stable economic growth of Russia and moderate unemployment rate from 2005 to 2015, among other things, was caused by the favorable oil price. Thereby this paper supports the findings of Melnikov R., (2010), Gostev A., (2016) and others.

The study analyzed only the interaction between three basic macroeconomics indicators and oil price, but the future direction of the research will be to expand the research area by including indicators like foreign direct investments, exchange rate, national export and import and etc. Such manipulation is expected to improve the quality of the investigation and enables to make more precise policy recommendations.

\section{Acknowledgments}

The work is performed according to the Russian Government Program of Competitive Growth of Kazan Federal University.

\section{References}

1. Ghalayini, L., 2011. The Interaction between Oil Price and Economic Growth. Middle Eastern Finance and Economics, 13, pp. 127-141.

2. Beaudreau, B.C., 2005. Engineering and economic growth. Structural Change and Economic Dynamics, 16 (2), pp. 211-220.

3. Fawad, A., 2013. The Effect of Oil Prices on Unemployment: Evidence from Pakistan. Business and Economics Research, 1(17) pp. 43-57.

4. Melnikov, R., 2010. Influence of the dynamics of oil prices on the macroeconomic indicators of the Russian economy. Applied Econometrics Journal, pp. 20-29.

5. Gostev, A., 2016. The problem of the oil needle in Russia. Actual problems of aviation and cosmonautics, 2 (12) pp. 1149-1150.

6. Benedictow, A., Fjærtoft D. and Løfsnæs O., 2013. Oil dependency of the Russian economy: An econometric analysis. Economic Modelling, pp. 400428.

7. Johansen, S., 1988. Statistical analysis of cointegration vectors. J. Econ. Dyn. Control 12, 231-254.

8. Johansen, S., 1995. Likelihood-based Inference in Cointegrated Vector Autoregressive Models. Oxford University Press, Oxford.

9. Breusch, T., Godfrey, L.G., 1981. A review of recent work on testing for autocorrelation in dynamic simultaneous models. In: Currie, D., Nobay, R., Peel, D. (Eds.), Macroeconomic Analysis: Essays in Macroeconomics and Econometrics. Croon Helm, London, pp. 63-105.

10. Mironov, V., Petronevich, A., 2015. Discovering the signs of Dutch disease in Russia. Resources Policy. №. 46, pp. 97-112.

11. Kudrin, A., 2013. The Influence of Oil and Gas Exports on Russia's Monetary Policy. Economic issues, 3 pp. 4-18. 